\title{
Plaučių vėžys: kaip pailginti pacientų gyvenimo trukmę
}

\author{
Margarita Lapènaitè, Marius Žemaitis \\ LSMU MA Pulmonologijos ir imunologijos klinika
}

Reikšminiai žodžiai: plaučių vėžys, spindulinė terapija, chemoterapija, taikinių terapija, imunoterapija, chirurginis gydymas. Santrauka. Plaučių vėžys - viena iš didžiausią mirtingumą lemiančių onkologinių ligų Lietuvoje ir pasaulyje. Pasaulio sveikatos organizacijos duomenimis, 2012 m. nuo plaučių véžio mirè 1,59 mln. žmonių, o tai sudaro 19 proc. visų mirčių dèl onkologinių ligų. Lietuvoje 2011 m. naujai diagnozuoti 17862 susirgimai onkologine liga, iš jų net 9 proc. plaučių vėžiu, o nuo šios ligos tais pačiais metais mirè 17 proc. visų ligonių. Irodyta, kad plaučių vė̌zio išsivystymui didžiausią įtaką turi rūkymas. Didesnis per dieną surūkomų cigarečių skaičius bei ilgesnẻ bendra rūkymo trukmė smarkiai didina riziką susirgti plaučiu vèžiu. Rūkančiuju rizika susirgti plaučių vėžiu, lyginant su nerūkančiais, išauga 30 proc. [1]. Plaučių věžiu paprastai suserga vyresnio amžiaus žmonės. Jaunesni nei 45 m. amžiaus asmenys sudaro tik 2 proc. plaučių vẻžio ligonių. Manoma, jog sergamumas šia liga ateinančiais dešimtmečiais gali išaugti 3 kartus. Išgyvenamumą sergant plaučių vėžiu lemia daugybė aspektų: ankstyva diagnostika, naujos plaučių vė̌zio gydymo ir diagnostikos galimybės, geresnė gydymo komplikacijų bei ligos simptomų kontrolè, geriausia palaikomoji priežiūra.

\section{PLAUČIŲ VĖŽIO PATOGENEŻ̇}

Plaučių vėžio patogenezė nėra visiškai aiški. Žinoma, jog onkologinių ligų atsiradimą lemia organizmo ląstelių transformacija i vẻžines ląsteles. Tam įtakos turi genetiniai, išorès veiksniai: fiziniai kancerogenai (UV ir jonizuojančioji spinduliuotè), cheminiai kancerogenai (asbestas, tabako dūmai, arsenas), biologiniai kancerogenai (virusai, bakterijos, parazitai). Imuninè sistema labai svarbi plaučių véžio patogenezèje, nes imuninès ląstelès neatpažįsta pakitusių vẻžinių ląstelių. Tokiomis sąlygomis nulemiamas vèžio augimas ir metastazavimas.

Dabarties medicinoje itin daug dėmesio skiriama pacientu gyvenimo trukmès ilginimui ir gyvenimo kokybès gerinimui. Išgyvenamumui didelę įtaką turi efektyvus ligos gydymas, šiomis dienomis teikiantis nemažai galimybių ir pasirinkimų.

Pagrindiniai plaučių vèžio gydymo būdai yra operacinis gydymas, spindulinis gydymas ir (arba) chemoterapija, taikinių terapija. Plaučių vẻžio gydymo taktika parenkama daugiadisciplinio aptarimo metu, kai ịvertinama paciento būklè, vėžio histologinis tipas, stadija. Taikant standartinius gydymo metodus, véžio registro duomenimis, vyrų pacientų, sergančių plaučių véžiu, 5 metų išgyvenamumas Lietuvoje siekia 6,4 proc., moterų - 9,9 proc. [2].

\section{PLAUČIŲ VĖŽIO ANKSTYVOJI DIAGNOSTIKA}

Pacientų, sergančių plaučių vẻžiu, išgyvenamumą pailgina ankstyva plaučių vẻžio diagnostika. 2011 metais atliktų tyrimų duomenimis (angl. The National Lung Screening Trial), didelę riziką susirgti plaučių vẻžiu turinčių pacientų patikra mažų dozių krūtinès ląstos kompiuterine tomografija sumažino mirštamumą 20 proc. 75 proc. pacientuc nustatoma jau pažengusi ar išplitusi liga, todèl 5 metu išgyvenamumas siekia vos 5 proc.

\section{OPERACINIS PLAUČIU VĖŽIO GYDYMAS IR ADJUVANTINE CHEMOTERAPIJA}

Operacinis gydymas taikomas pacientams, kurie serga I, II, retai IIIA stadijos nesmulkiụjų ląstelių plaučių vẻžiu (NSLPV), po kurio dar gali būti skiriama chemoterapija ir spindulinis gydymas. Kokia taktika bus taikoma, priklauso nuo naviko lokalizacijos (gali būti atliekama lobektomija, segmentektomija, polisegmentektomija, pulmonektomija). Atsižvelgiant i nustatytą vèžio stadiją, prieš operaciją gali būti taikomas neoadjuvantinis sutaptinis chemospindulinis gydymas, po kurio, pakartotinai įvertinus naviko tinkamumą operuoti, taikomas operacinis gydymas ir pooperacinè chemoterapija. Svarbiausias plaučių véžio 
operacinio gydymo tikslas - radikalumas. Po operacijos ivertinami rezekcijos kraštai, jei yra navikinè infiltracija, rekomenduojama pakartotinė rezekcija be chemoterapijos ar su ja arba spindulinis gydymas be chemoterapijos ar su ja. Operacija yra radikali, kai rezekcijos kraštuose ir sritiniuose limfmazgiuose nerandama navikinès infiltracijos. Pacientui parenkamas individualus, optimalus gydymas bei tikimasi geriausių rezultatų.

Adjuvantinè chemoterapija platinos pagrindu, klinikiniu tyrimu duomenimis (angl. the International Adjuvant Lung Cancer Trial, European Big Lung, the Adjuvant Lung Project Italy), sumažino 5 metų mirtingumą 5,4 proc. Adjuvantinè chemoterapija daugiausia reikšmès turejjo gydant II ir IIIA stadijos NSLPV. Adjuvantinès chemoterapijos nauda IB stadijos NSLPV nebuvo statistiškai reikšminga, o pacientams, sergantiems IA stadijos NSLPV, adjuvantinè chemoterapija sumažino išgyvenamumo vidurki [3-6]. Tarptautiniame klinikiniame tyrime (IALT) tirtas adjuvantinès chemoterapijos efektyvumas gydant I, II, III stadijos NSLPV, lyginant su pacientu stebejimu. Tirti 1867 pacientai, kurie sirgo I, II, III stadijos NSLPV bei buvo gydyti chirurginiu būdu. Nustatyta, kad 5 metų išgyvenamumas, skiriant adjuvantinę chemoterapiją, buvo ilgesnis (44,5 proc.) nei pacientu, kuriems adjuvantinis gydymas nebuvo skirtas $(40,4$ proc.) [3, 7].

Po chirurginio gydymo adjuvantinis spindulinis gydymas skiriamas esant navikinei infiltracijai rezekcijos kraštuose ir (ar) pažeistiems sritiniams limfmazgiams (N2). Analizuoti duomenys pacientų, sirgusių IIIA stadijos NSLPV, kuriems buvo taikytas chirurginis gydymas 2006-2010 metais JAV (angl. the National Cancer Data Base) ir pooperacinis spindulinis gydymas. Išgyvenamumo trukmès mediana skiriant pooperacinị spindulini gydymą buvo 45,2 mèn., o neskiriant - 40,7 mèn. 5 metų išgyvenamumas skiriant adjuvantini spindulinị gydymą buvo 39,3 proc., neskiriant - 34,8 proc. [8].

Kuo labiau pažengusi liga, tuo pacientų išgyvenamumas prastesnis. NSLPV sergančių pacientų 5 metų išgyvenamumas (angl. the Surveillance, Epidemiology and End Results) pagal plaučių vèžio stadiją: IA - 73 proc., IB - 58 proc., IIA - 46 proc., IIB - 36 proc., IIIA - 24 proc. [9].

\section{SPINDULINIS PLAUČIŲ VĖŽIO GYDYMAS}

Spindulinis plaučių vẻžio gydymas pirmą kartą buvo panaudotas daugiau nei prieš šimtmetị. Spindulinio gydymo esmé - jonizuojančiąja spinduliuote suardant DNR grandinę, siekiama pažeisti vèžinès ląstelès DNR. Taip gydant pažeidžiami ir sveikieji audiniai, tačiau jie geba greičiau regeneruoti dèl tam tikrų molekulinių mechanizmų, atkuriančių pažeistas DNR jungtis, kurių stokoja vẻžinès ląstelès [10]. Spindulinis gydymas gali būti radikalus, skiriamas kartu su chemoterapija, adjuvantinis ir paliatyvusis. Spindulinio gydymo skyrimą, dozę bei jo trukmę lemia ligonio bendra būklè, věžio stadija bei lokalizacija. Taikant radikalų spindulinị gydymą išgyvenamumas 5 metus siekia 20 proc. Pagal plaučių véžio diagnostikos ir gydymo rekomendacijas, adjuvantinis spindulinis gydymas turètu būti pradètas praejjus ne daugiau kaip 4-6 savaitèms po chirurginio gydymo. Paliatyvusis spindulinis gydymas skirtas paciento gyvenimo kokybei pagerinti lengvinant tam tikrus simptomus.

Stereotaktinè spindulinè terapija (SST) - tai technika, kai navikas švitinamas didelėmis spinduliuotès dozėmis, minimaliai sumažinant jos kiekị, tenkantị gretimiems audiniams. SST gydymas trumpas, nes skiriama nuo 1 iki 5 frakcijų po 1-34 Gy. Lietuvos sveikatos mokslų universiteto ligoninès Kauno klinikose (LSMUL KK) SST taikoma 4-5 metus. Šis gydymas skiriamas I ar II plaučių véžio stadija sergantiems pacientams, kuriems negalimas operacinis gydymas arba jie dèl tam tikruc priežasčių jo atsisako. Šio gydymo indikacijos: neoperuojamas, periferinis navikinis darinys iki $5 \mathrm{~cm}$ skersmens be limfmazgių pažeidimo. Lietuvoje šis gydymas taikomas tik histologiškai verifikuoto plaučių vèžio atvejais, o kai kuriose šalyse skiriamas ir histologiškai neverifikuotam plaučiu věžiui gydyti. Dviem trečios fazès klinikiniais tyrimais (STARS ir ROSEL), kuriuose lygintas I stadijos NSLPV operacinis ir stereotaktinès spindulinis gydymas, vertinant 58 tyrimo dalyvių išgyvenamumą (31 gydytas SST, 28 operuoti), nustatyta, kad SST gydytų tiriamųjų 3 metú išgyvenamumas sieké 95 proc., o operuotų - 79 proc. [11].

\section{PLAUČIŲ VĖŽIO GYDYMAS TAIKINIŲ TERAPIJOS IR IMUNOTERAPIJOS PREPARATAIS}

Chemoterapija platinos pagrindu (cisplatina ar karboplatina) ir vienu iš trečios kartos antinavikinių vaistų (docetakseliu, paklitakseliu, gemcitabinu, vinorelbinu) lemia ilgesnę gyvenimo trukmę, lyginant su chemoterapija platinos preparatu ir antros eilès antinavikiniu vaistu (pvz., etapozidu) [12]. Chemoterapiniai vaistai veikia greitai besidauginančias ląsteles skirtinguose jos dalijimosi cikluose. Jie nèra selektyvūs véžinèms ląstelèms, dèl to veikia ir kitas, greitai besidalijančias kaulų čiulpų, odos, žarnyno ląsteles. Tai lemia šalutinius chemoterapijos reiškinius: plaukų slinkimą, kraujo ląstelių sumažejimą.

Taikinių terapija - vienas iš naujausių ir pažangiausių plaučių vẻžio gydymo metodų, pailginančių NSLPV sergančių pacientų gyvenimo trukmę. Gydymo esmè esant EGFR geno mutacijai ir ALK geno translokacijai, skiriant tirozino kinazès inhibitorius ar monokloninius antikūnus, sustabdomas vėžinių ląstelių augimas. Šis gydymas skiriamas pacientams, kurių liga jau yra pažengusi. EGFR - ląstelès baltymas, atsakingas už jos augimą. Esant EGFR mutacijai (kai yra histologiškai patvirtinta adenokarcinoma ir didelių ląstelių karcinoma), skiriamas tirozino kinazès inhibitorius erlotinibas, gefitinibas arba afatinibas. Tirozino kinazès - fermentai, atsakingi už daugelio baltymų aktyvaciją per kinazių kaskadas (signalo perdavimo kelius). Tirozino kinazès inhibitoriai, blokuodami specifinius vėžinių ląstelių receptorius, blokuoja signalo perdavimą vẻžinei ląstelei - taip stabdo jos gebą daugintis ir ląstelè žūva. Gydant tirozino kinazès 
inhibitoriais, pacientų išgyvenamumo mediana geresnè - ji siekia 27 ménesius. Sergant pažengusiu nesmulkiųjų ląstelių plaučių vèžiu, taip pat tiriama ALK geno translokacija. ALK - anaplastinès limfomos kinazė, priklausanti tirozino kinazès baltymų šeimai. Esant ALK geno mutacijai, ląstelès greičiau auga ir metastazuoja. Nustačius ALK translokaciją, efektyvus yra ALK inhibitorius krizotinibas. Krizotinibas, slopindamas ALK receptorius, slopina véžinès ląstelès augimą ir sukelia jos žūtị. Jis skirtas išplitusiam, anksčiau gydytam, nesmulkiųjų ląstelių plaučių véžiui gydyti. Ceritinibas yra antros kartos ALK inhibitorius, skirtas gydyti pacientus, kuriems liga progresuoja gydant krizotinibu, taip pat tiems, kurie jo netoleruoja.

Vienas iš inotyviausių pažengusio vẻžio gydymo būduc yra imunoterapija. Imunoterapijos tikslai: padèti organizmo imuninei sistemai atpažinti vẻžinę ląstelę, stimuliuoti imunini atsaką bei sumažinti imuninès sistemos toleranciją pakitusioms ląstelèms. Sèkmingas imuninès sistemos pakitusių ląstelių likvidavimas susideda iš kelių pakopuc. Imuninès sistemos pagrindiné funkcija - atpažinti organizmui svetimas ar pakitusias ląsteles. Sergant onkologine liga slopinamas imuninès sistemos atsakas, dèl to išsivysto imuninè tolerancija navikinèms ląstelèms ir susidaro palankios sąlygos šių ląstelių proliferacijai. Iprastai antigeną pateikianti ląstelè pristato naviko antigeną $\mathrm{T}$ limfocitams per specifinius $\mathrm{T}$ ląstelès receptorius. Taip suaktyvejjusios $\mathrm{T}$ ląstelès atpalaiduoja citolizinius fermentus bei citokinus ir sunaikina navikines ląsteles. Navikinès ląstelès, siekdamos išvengti imuninès sistemos atsako, tam tikrais ligandais (PDL1, CTLA-4) jungiasi prie $\mathrm{T}$ limfocitu paviršiuje esančių receptorių ir inaktyvuoja $\mathrm{T}$ limfocitus, inkatyvuojant ir slopinant imunini atsaką. Imunoterapijai vartojami antikūnai jungiasi prie $\mathrm{T}$ limfocituc esančiuc receptorių, juos blokuoja ir neleidžia navikiniu ląstelių ligandams prisijungti prie $\mathrm{T}$ limfocitu ir slopinti imuninio atsako. Jau yra sukurti vaistai, blokuojantys navikinių ląstelių paviršiuje esančius ligandus, tačiau vaistas, kurị galima taikyti klinikinejje praktikoje dar nesukurtas.

Melanomos ir plaučių véžio ląstelès skiriasi nuo kitų organų labai dideliu mutacijų skaičiumi jose. Navikai, turintys daug somatinių mutacijų, pasižymi geresniu atsaku ì gydymą $[13,14]$. Vieno klinikinio tyrimo duomenimis, NSLPV sergantys pacientai, kuriems buvo skirtas anti-PD1, klinikinis atsakas koreliavo su mutacijų skaičiumi [15].

Kadangi imunoterapija šiuo metu laikoma daug žadančia plaučiuc vèžio gydymo kryptimi, atliekami îvairūs klinikiniai tyrimai, kuriuose tiriamas imunoterapinių vaistų grupès - monokloninių antikūnų - veiksmingumas. Monokloniniai antikūnai - tai žmogaus sukurtos molekulès, kurios sąveikauja su specifiniais vèžio ląstelès antigenais. Ši sąveika inaktyvina véžio augimo receptorius ir skatina ląstelių apoptozę. Plaučių véžio gydymas imunoterapija šiuo metu nèra patvirtintas. Lietuvoje ir visame pasaulyje atliekami šio naujo plaučiu vėžio gydymo metodo klinikiniai tyrimai. Intensyviai tyrinejami programuotos ląstelių žūties 1 (angl. Programmed cell Death-1, PD1) signalinis kelias ir programuotos ląstelių žūties ligandas 1 (angl. Programmed cell death $\mathrm{Li}$ gand-1, PDL-1).

\section{GERIAUSIA PALAIKOMOJI PRIEŽIŪRA}

Tai pacientų, sergančių progresuojančiu ar išplitusiu plaučių vẻžiu, gydymas ir slauga. Geriausia palaikomoji priežiūra yra orientuota i̇ konkretų asmení, jo ligos sukeltuc problemų sprendimus ir ligonio būklès palengvinimą bei dar likusio gyvenimo sąlygų gerinimą. Stengiamasi mažinti ilgalaikio gydymo padarinius, ypač skausmą, laiku teikti visą imanomą specialistų pagalbą. Taikomas paliatyvusis spindulinis, operacinis gydymas, paliatyviosios invazinès procedūros.

Tokia priežiūra tiesiogiai nelemia ilgesnès gyvenimo trukmès, bet gydytojų, slaugytojų, psichologų teikiamos pagalbos sergančiam asmeniui tikslas - užtikrinti geriausią ìmanomą gyvenimo kokybę.

\section{LUNG CANCER: HOW TO EXTEND THE LIVES OF PATIENTS}

MARGARITA LAPÉNAITÉ, MARIUS ŽEMAITIS

DEPARTMENT OF PULMONOLOGY AND IMMUNOLOGY ACADEMY OF MEDICINE LITHUANIAN UNIVERSITY OF HEALTH SCIENCES

Keywords: lung cancer, radiation therapy, chemotherapy, targeted therapy, immunotherapy, surgical treatment. Summary. Lung cancer - one of the highest mortality rate of oncological diseases determining illness in $\mathrm{Li}$ thuania and all over the world. According to The World Health Organization, of lung cancer died 1.59 million. people in 2012, accounting for $19 \%$ of all deaths due to onco-logical diseases. In 2011, 17862 people were diagnosed with cancer in Lithuania, of which $9 \%$ were lung cancer cases. It has been shown that the greatest impact on lung cancer devel-opment has smoking.The risk of developing lung cancer increases with the number of cigarettes smoked per day and duration of smoking. Smokers' risk of developing lung cancer increases by 30proc. when compared to non-smokers. Generally, older people are suffering from lung cancer. Only $2 \%$ of lung cancer cases consists of younger people than 45 years old. It is estimated that the incidence of this disease in the coming decades can be increased by 3 times. Many aspects lead to lung cancer survival:early diagnosis, new lung cancer diagnostic and treatment options, better control of complications and symptomsand the best supportive care.

\section{LITERATŪRA}

1. Samet $J M$, Wiggins $C L$, Humble CG, Pathak DR. Cigarette smoking and lung cancer in New Mexico. Am Rev Respir Dis 1988; 137:1110.

2. Smailyté G, Aleknavičiené B. Véžys Lietuvoje 2011 metais; 2011

3. Arriagada R, Bergman B, Dunant A, et al. Cisplatin-based adjuvant chemotherapy in patients with completely resected non-small-cell lung cancer. N Engl J Med 2004; 350:351.

4. Waller D, Gower N, Milroy MD, et AL.. The Big Lung Trial: determining the value of cisplatinbased chemotherapy for all patients with nonsmall cell lung cancer (NSCLC). Preliminary results in the surgical setting (abstract). Proc Am Soc Clin Oncol 2003; 22:639.

5. Scagliotti GV, Fossati R, Torri V, et al. Randomized study of adjuvant chemotherapy for completely resected stage I, II, or IIIA non-small-cell Lung cancer. J Natl Cancer Inst 2003; 95:1453.

6. Pignon JP, Tribodet H, Scagliotti GV, et al. Lung adjuvant cisplatin evaluation: a pooled analysis by the LACE Collaborative Group. J Clin Oncol 2008; 26:3552.

7. Arriagada R, Dunant A, Pignon JP, et al. Long-term results of the international adjuvant lung cancer trial evaluating adjuvant Cisplatin-based chemotherapy in resected lung cancer. J Clin Oncol 2010 28.35.

8. Cliff G Robinson,Aalok P. Patel, Jeffrey D. Bradley, Todd DeWees, Saiama N. Waqar, Daniel Morgensztern, Maria Q. Baggstrom et al. Postoperative Radiotherapy for Pathologic N2 NonSmall-Cell Lung Cancer Treated With Adjuvan Chemotherapy: A Review of the National Cancer Data Base; Journal by Clinical Oncology; 2015.

Kiti literatūros šaltiniai (iš viso 15) redakcijoje. 